\title{
A DEMOUNTABLE WAVE ABSORBER FOR WAVE FLUMES AND BASINS
}

\author{
Simon Tiedeman ${ }^{1}$, William Allsop ${ }^{1}$, Viviana Russo ${ }^{2}$ and Andy Brown ${ }^{1}$
}

Passive wave absorption is an integral component of the physical modeling environment, used to minimise unwanted reflections of wave energy that compromise test results. This paper reviews data for methods of passive absorbers and then extends this knowledge through the design and implementation of a device that can be removed from the working water surface. The modeling tests that were carried out in this paper demonstrate that a parabolic spending beach can perform by absorbing waves with coefficients of reflection $\mathrm{C}_{\mathrm{r}(\text { energy) }}$ significantly $<10 \%$.

Keywords: wave absorber; passive absorption; removable beach; wave energy dissipation

\section{INTRODUCTION}

Ship towing tanks generally use wave action against or with the direction of ship travel. Recent developments however now often need the generation of transverse waves, requiring the provision of wave makers along a major proportion of the towing tank length. A similar length of wave absorbing beach is then required along the opposite side of the tank to avoid corrupting the test waves along the vessel path. HR Wallingford have designed wave makers and absorbing beaches for large scale physical modelling facilities where :

- $\quad$ Length $=130+$ m; Width $=35+\mathrm{m}$

- $\quad$ Overall tank depth $=6 \mathrm{~m}$; Working depth $=5 \mathrm{~m}$

- Performance requirements for the wave generator and wave absorbing beaches of $\mathrm{H}_{\mathrm{s}}=0.35 \mathrm{~m}$, with $\mathrm{T}_{\mathrm{p}}=2$ to $3 \mathrm{~s}$ and passive beach absorbers with $\mathrm{C}_{\mathrm{r}(\text { energy })}<10 \%$

None of these criteria are particularly onerous, except the additional requirement for a recent project that the entire length of passive absorber must be removed or folded out of the way in 60 minutes to allow the full width of the tank to be used for ship towing tests without the transverse wave. This requirement immediately eliminates the opportunity to use armoured (open granular) slopes or perforated cages filled with open cell foam. Even multiple perforated screens would be difficult to fold or heavy to lift out. This paper describes the initial review of different options, the two stages of conceptual then final design development and finally the proving tests of the chosen design prototype.

\section{METHODOLOGY}

The project plan was devised in two stages. The primary stage set out to review the existing forms of passive absorption systems that could be implemented within the physical modelling environment. The objective of this stage was to identify documented research to evaluate the following three main areas:-

- The ability to perform to the required hydraulic performance criteria

- $\quad$ Potential for the design to be removed easily

- $\quad$ Ease and likely cost of fabrication

Once the range of documented absorption systems had been identified it would be necessary to select the most efficient and suitable type for conducting a series of physical modelling tests to demonstrate that these proposed performance statistics could be replicated.

The second stage of the project would then look to investigate further optimisation of the device and conclusively demonstrate the optimum configuration for absorber performance using a second physical model at a larger scale.

\footnotetext{
${ }^{1}$ HR Wallingford, Howbery Park, Wallingford, Oxfordshire, OX10 8BA, UK

${ }^{2}$ Queen's University Belfast (previously visiting researcher to HR Wallingford Ltd from Università Mediterranea di Reggio Calabria, Italy)
} 


\section{RESEARCH}

\section{Stage 1 Literature Review}

The literature review phase identified a range of existing types of passive absorption systems

- Voided chambers

- $\quad$ Perforated screens

- $\quad$ Open metal cages with additional porous material

- $\quad$ Sloping faced systems (permeable / impermeable)

- $\quad$ Parabolic faced systems (permeable / impermeable)

- Nests of open pipes (variable length) forming resonant arrays

- Various combinations of the above

At the conclusion of this review, two main systems with potentially similar performance were selected for further evaluation during the Stage 1 modelling tests. These systems consisted of a set of vertical perforated sheets; or a perforated parabolic sloping design as shown in the Figures 1 and 2.

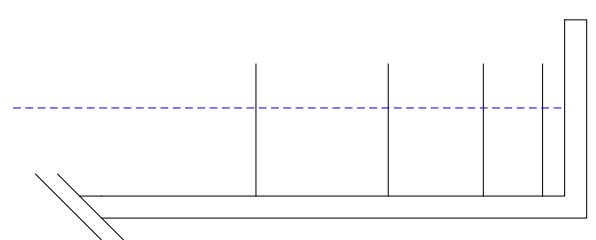

Figure 1:- Vertical perforated screens

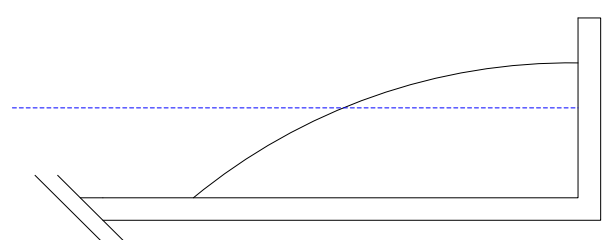

Figure 2:- Parabolic perforated slope

The literature review also highlighted that existing performance data were generally only available for relatively shallow water applications. This presented the first challenge to extend knowledge into deep water. Experience using an offshore tank at HR Wallingford identified that it was however possible to increase the usable area of a modelling facility by truncating a steep sloping beach to contain a simple (part-depth) vertical face, using the established $1 / 4$ wave interference effect to reduce reflections.

Analysis of wave orbital velocities for the periods of interest suggested that it would be possible to replicate this feature into the passive absorber design. The interpretation of this assumption is shown in Figures 3 and 4.

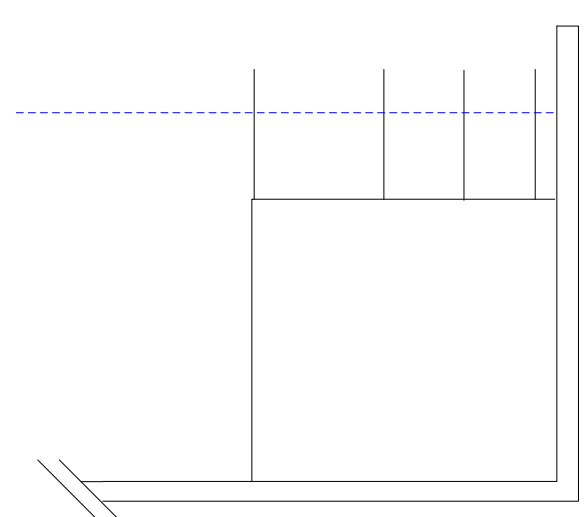

Figure 3:- Deepwater vertical perforated screens

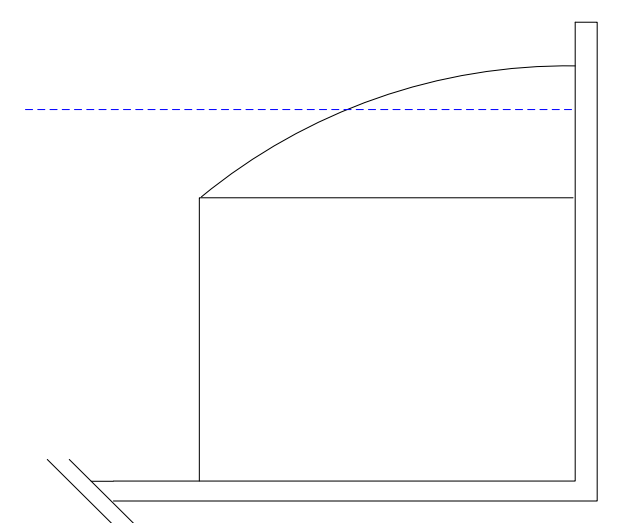

Figure 4:- Deepwater parabolic perforated slope

Both options represented innovative steps from current designs so the reflection performance of the new designs could not simply be extrapolated from previous data. It was therefore essential that the new designs were tested in a hydraulic model. 


\section{Stage 1 Modelling Tests}

The two Stage 1 models were designed at a scale of 1:4, with a (model) water depth of $1.25 \mathrm{~m}$ and an overall length for the model of $1.13 \mathrm{~m}$. Four irregular wave conditions characterised by the JONSWAP spectra, with nominal wave periods of $\mathrm{T}_{\mathrm{p}}=2 \mathrm{~s}$, 3s, $4 \mathrm{~s}$ and $5 \mathrm{~s}$ (prototype units) were tested. The wave height was set at $\mathrm{H}_{\mathrm{s}}=0.35 \mathrm{~m}$ (prototype units) for all tests.

The active length of the test flume used for these experiments was approximately $25 \mathrm{~m}$. A four probe array was used to determine the Reflection coefficient ' $\mathrm{C}_{\mathrm{r}}$ ' with analysis using Mansard \& Funke (1980), modified by Isaacson (1991) and Zelt \& Skjelbreia (1992). The flume configuration is shown in Figure 5.

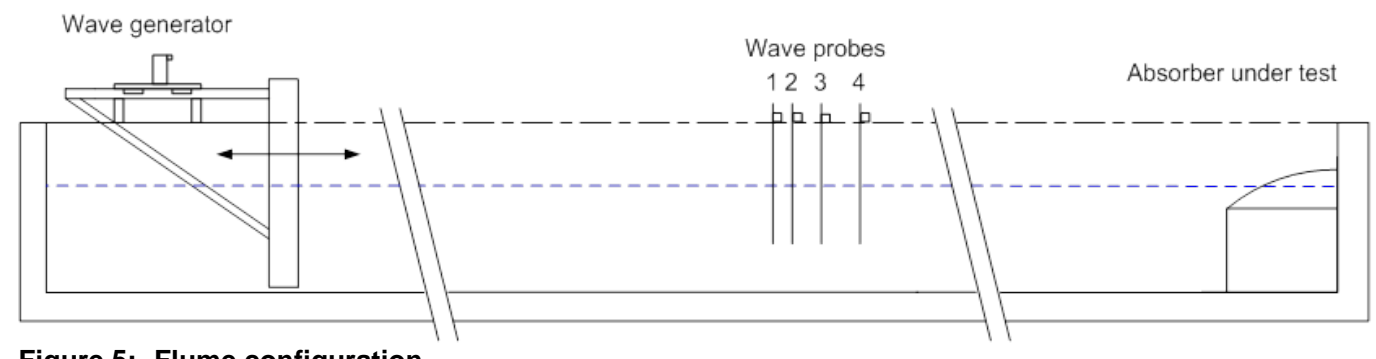

Figure 5:- Flume configuration

The selection of materials, able to represent the key characteristics of available prototype materials, was overcome particularly for the parabolic design, by incorporating multiple perforated sheets to open and close the perforation density. This resulted in a larger range of perforation densities being evaluated and facilitated lower model fabrication costs. Figures 6 and 7 show both models prior and during evaluation tests.
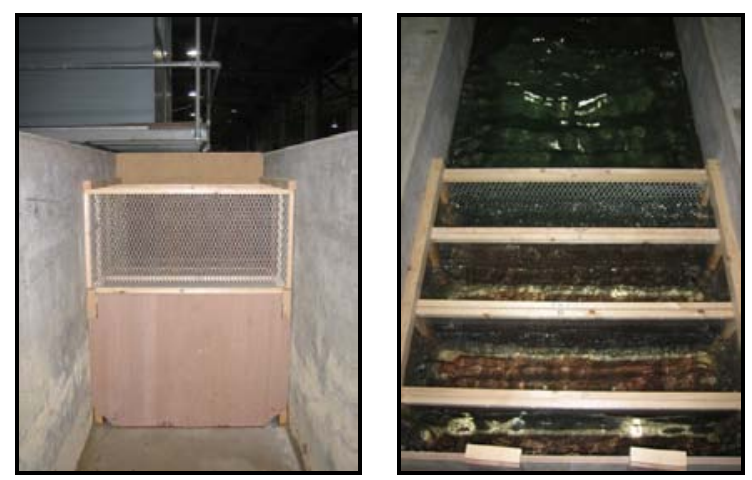

Figure 6:- Vertical screen installation and under test
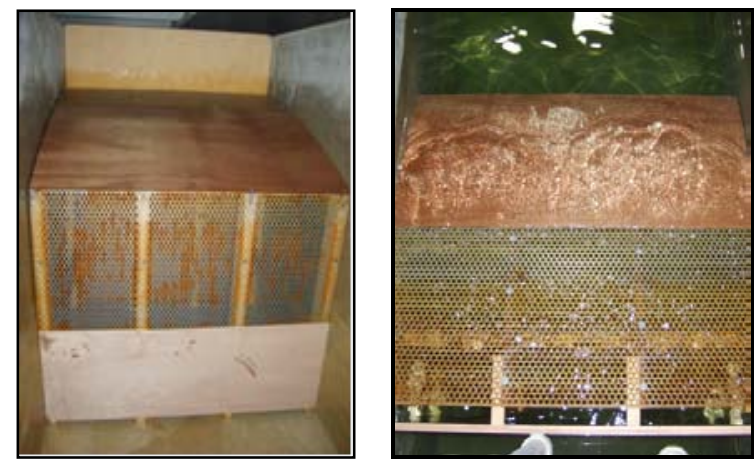

Figure 7:- Parabolic slope installation and under test 
The absorption results from this phase indicated that both of these systems are capable of achieving the required performance criteria of $\mathrm{C}_{\mathrm{r}(\text { energy) }}<10 \%$. It was therefore necessary to evaluate the two systems against the additional requirement of allowing the system to be removed or folded into the tank and also the economic impact of fabricating the design. This evaluation is summarised in Figure 8.

\begin{tabular}{|c|c|c|c|}
\hline \multicolumn{2}{|c|}{ Vertical Screens } & \multicolumn{2}{c|}{ Parabolic Perforated Screen } \\
\hline $\begin{array}{c}\text { Advantages } \\
\text { performance criteria } \\
\text { of } \mathrm{C}_{\mathrm{r}(\text { energy })<10 \%}\end{array}$ & $\begin{array}{c}\text { Disadvantages } \\
\text { Screens extend } \\
\text { further into tank to } \\
\text { absorb longer wave } \\
\text { lengths }\end{array}$ & $\begin{array}{c}\text { Advantages } \\
\text { Meets required } \\
\text { performance criteria } \\
\text { of } \mathrm{C}_{\mathrm{r}(\text { energy) }}<10 \%\end{array}$ & $\begin{array}{c}\text { Greater accuracy } \\
\text { needed to } \\
\text { fabricate the } \\
\text { parabola }\end{array}$ \\
\hline & $\begin{array}{c}\text { Sheets become } \\
\text { deformed easily } \\
\text { with wave action }\end{array}$ & $\begin{array}{c}\text { Shorter protrusion } \\
\text { into the tank }\end{array}$ & $\begin{array}{c}\text { Difficult to } \\
\text { optimise } \\
\text { perforation density }\end{array}$ \\
\hline & $\begin{array}{c}\text { Complicated folding } \\
\text { to hechanism leading }\end{array}$ & $\begin{array}{c}\text { Best performance } \\
\text { identified when there } \\
\text { are no perforations } \\
\text { in the front panel }\end{array}$ & \\
\hline & $\begin{array}{c}\text { Single drive } \\
\text { actuation required to } \\
\text { lower the structure }\end{array}$ & \\
\hline
\end{tabular}

Figure 8:- Evaluation summary output from Stage 1 data review

From this evaluation the parabolic perforated screen design was selected for Stage 2 evaluation.

\section{Stage 2 Modelling Tests}

The further development of the passive absorber in Stage 2 required the selected design to be tested at a larger scale, re-confirming the performance capability of the system, and allow optimisation of the perforation density and measuring pressures / loadings that could be used for the mechanical design stage.

A scale of 1:2 was selected for these tests, but a limitation in the flume size available at the time lead to difficulties in matching the required water depth. A review of wave orbital velocities, analysed for the prototype water depth across the range of wave periods, suggested however that orbital velocities over the lower part were negligible below $50 \%$ of the water depth. These models were therefore truncated to only half the prototype depth. Dimensions of the model structure, as tested in stage 2, are shown in Figure 9.
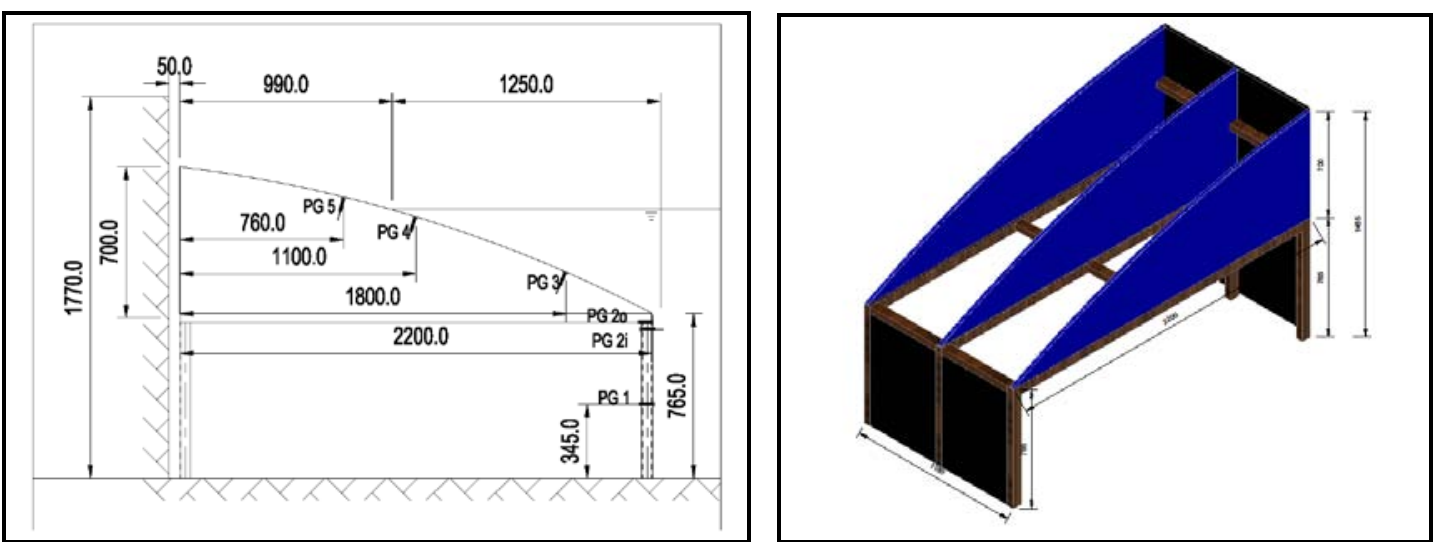

Figure 9:- Stage 2 model design (Dimensions in $\mathrm{mm}$ ) 
The model was fitted with pressure gauges to measure wave pressures, and to identify any effect of rundown on the solid front section of the parabolic beach panel.

In addition to the wave spectra tested in Stage 1, the Stage 2 model was tested with a series of Pink Noise (Top Hat) spectra, which is the recommended method for providing an even quantity of energy across a defined frequency range. Three Pink Noise spectra were selected to cover the expected range of frequencies that the absorber would be used over, these are shown in Figure 10.

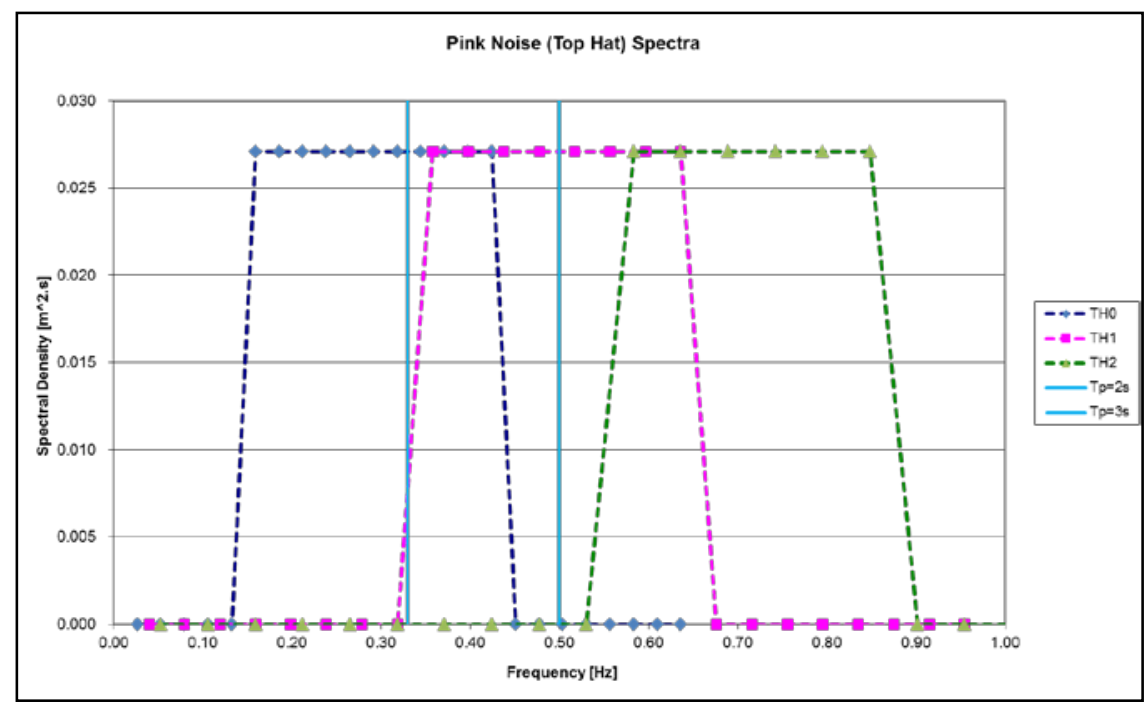

Figure 10:- Stage 2 Pink Noise spectra to determine reflection coefficients

A variety of key parameters were again investigated to optimise and tune the passive absorber. These parameters included the mean absorber immersion depth, front wall perforation density, parabola perforation density, surface roughness and special features such as sawtooth type retaining grooves. The results for these parameter changes are shown in Appendix 1.

The reflection performance of the optimum design configuration selected for the prototype absorber is shown in Figure 11.

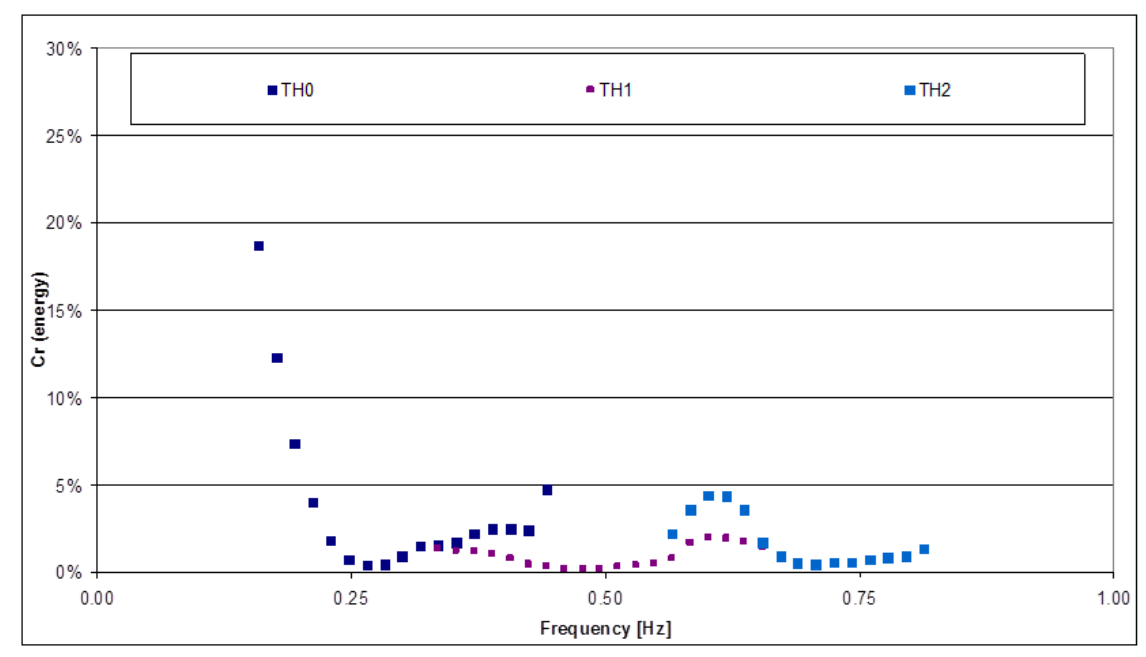

Figure 11:- Stage 2 absorber performance showing $C_{r(e n e r g y)}$ in optimum absorber configuration (Test TS06)

A review of the significance of these design parameters concluded that the most significant impact to the performance characteristics was to increase the immersion depth, i.e. lower the beach. The next significant parameter was the point at which perforations start in the parabola profile surface. It was 
also possible to reaffirm that the front panel should have a zero perforations as the optimum configuration. Surface undulations and roughness were considered to be the least important of the parameters considered.

\section{DETAIL DESIGN, FABRICATION AND PROTOTYPE TESTING}

The process to remove the passive absorber from the tank was selected following a review of the range of tank water depths and the available building space. This resulted in the beach being folded to the floor of the tank using a winch mechanism.

The forces derived from the testing phase in stage 2 of this study provided a good agreement with predicted force distribution formulae from Goda (1985) and Takahasi et al (1994). These were then used to design a substructure frame that would allow the beach to resist the dynamic wave impact energy and also allow the structure to be capable of folding onto the tank floor with the tank both empty and full of water. In order to maximise the expected equipment life span it was chosen to fabricate the beach from stainless steel.

To optimise the control for beach movement, in lowering and raising the structure, a series of buoyancy tanks were provided within the parabola to give the necessary positive lift to return the absorber to the surface when required by the facility operator. This had the effect of simplifying the lowering mechanism to a single winch wire system, which was located outside of the basin and used a number of cable sheaves allowing the cable to pass through the wall of the tank to reach the front of the beach frame.

The prototype beach was assembled and functionally tested at HR Wallingford to demonstrate the full geometry of the structure. The prototype was also used to prove the configuration of the buoyancy system located within the passive absorber. This was achieved by re-installing the beach within a basin and adjusting the water level to raise and lower the beach. Examples of these tests are shown in the figures 12 and 13.

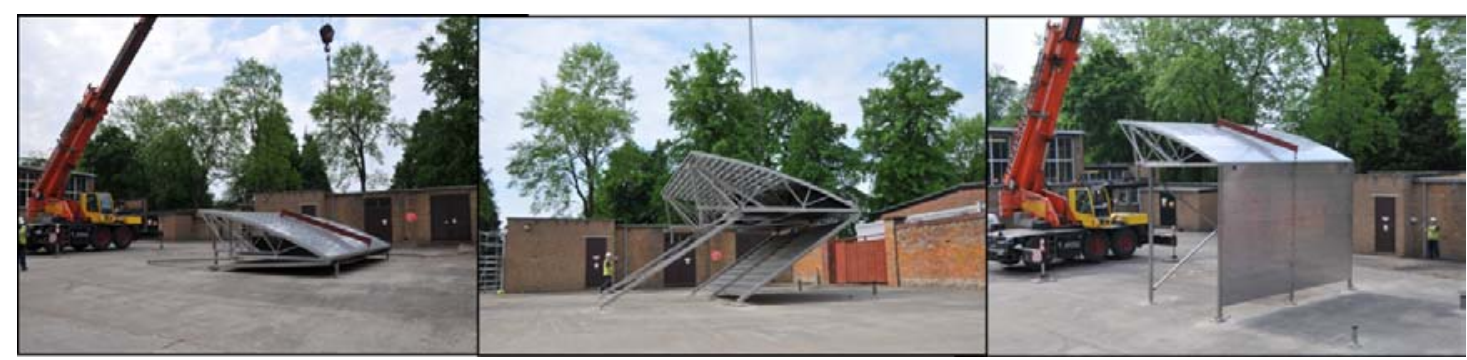

Figure 12:- Prototype lift test at HR Wallingford

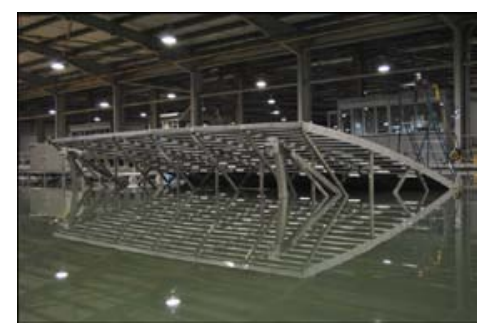

Figure 13:- Prototype absorber under flotation test at HR Wallingford

\section{CONCLUSIONS}

This study confirmed that both vertical and parabolic perforated passive absorption systems are capable of absorbing waves to coefficients of reflection ' $\mathrm{C}_{\mathrm{r} \text { (energy) }}<10 \%$. It is also possible to make such a device fold, although this will impact on the choice of beach construction. 
The analysis of the perforated parabolic passive absorption beach, selected for the stage 2 phase of the study, was tested to exceed a coefficient of reflection ' $\mathrm{C}_{\mathrm{r}(\text { energy) }}$ ' $<5 \%$ between the frequencies of 0.2 $\mathrm{Hz}$ and $0.8 \mathrm{~Hz}$.

At selected frequencies the coefficient of reflection ' $\mathrm{C}_{\mathrm{r}(\text { energy) }}$ ' for perforated parabolic beaches can be as low as $<1 \%$.

\section{ACKNOWLEDGMENTS}

This work was funded by HR Wallingford with technical support from Dr Russo from Università Mediterranea di Reggio Calabria, Italy.

\section{APPENDIX}

The following series of tests were conducted in Stage 2 that incorporated the following series of step changes:-

\begin{tabular}{|c|c|c|c|c|c|}
\hline $\begin{array}{l}\text { Figure } \\
\text { reference }\end{array}$ & Test & $\begin{array}{l}\text { Perforated } \\
\text { front wall }\end{array}$ & $\begin{array}{c}\text { Change to } \\
\text { mean water } \\
\text { level }\end{array}$ & $\begin{array}{c}\text { Change in \% } \\
\text { Perforation } \\
\text { Area }\end{array}$ & Surface features \\
\hline 14.1 & TS02 & $0 \%$ & $-0.25 \mathrm{~m}$ & $0 \%$ & Smooth \\
\hline 14.2 & TS03 & $40 \%$ & $-0.25 \mathrm{~m}$ & $0 \%$ & Rough \\
\hline 14.3 & TS04 & $0 \%$ & $-0.15 \mathrm{~m}$ & $0 \%$ & Rough \\
\hline 14.4 & TS05 & $0 \%$ & $-0.05 \mathrm{~m}$ & $0 \%$ & Rough \\
\hline 14.5 & TS06 & $0 \%$ & $0 \mathrm{~m}$ & $0 \%$ & Rough \\
\hline 14.6 & TS07 & $0 \%$ & $+0.05 \mathrm{~m}$ & $0 \%$ & Rough \\
\hline 14.7 & TS08 & $0 \%$ & $0 \mathrm{~m}$ & $-19.8 \%$ & Rough \\
\hline 14.8 & TS09 & $0 \%$ & $0 \mathrm{~m}$ & $-13.0 \%$ & Rough \\
\hline 14.9 & TS10 & $0 \%$ & $0 \mathrm{~m}$ & $-6.2 \%$ & Rough \\
\hline 14.10 & TS11 & $0 \%$ & $0 \mathrm{~m}$ & $-13.0 \%$ & $\begin{array}{c}\text { Rough with saw- } \\
\text { tooth ridges }\end{array}$ \\
\hline 14.11 & TS12 & $0 \%$ & $+0.05 \mathrm{~m}$ & $-13.0 \%$ & $\begin{array}{l}\text { Rough with saw- } \\
\text { tooth ridges }\end{array}$ \\
\hline 14.12 & TS13 & $0 \%$ & $+0.05 \mathrm{~m}$ & $-13.0 \%$ & Rough \\
\hline
\end{tabular}

Performance graphs for each of the above test series are shown in Figures 14.1-14.12.

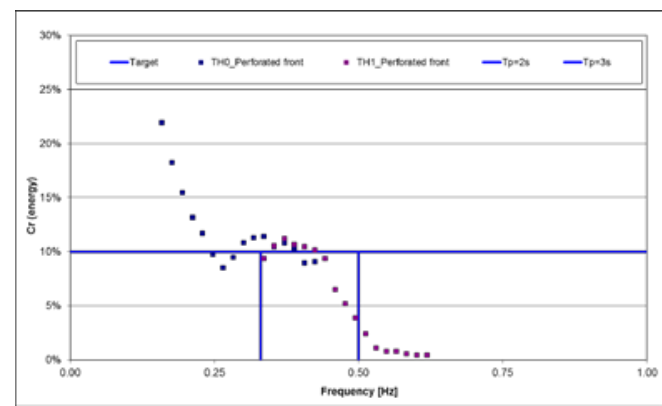

Figure 14.1

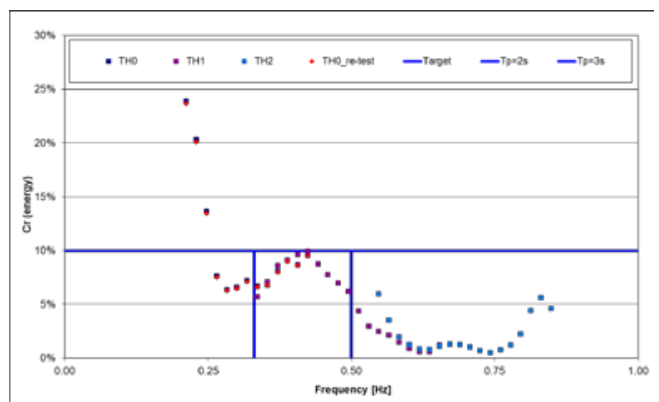

Figure 14.2 


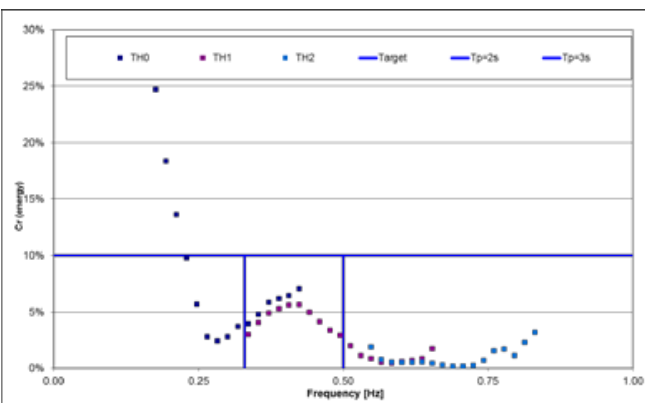

Figure 14.3

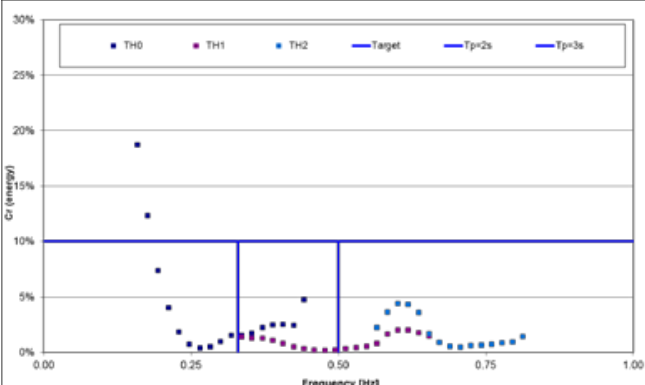

Figure 14.5

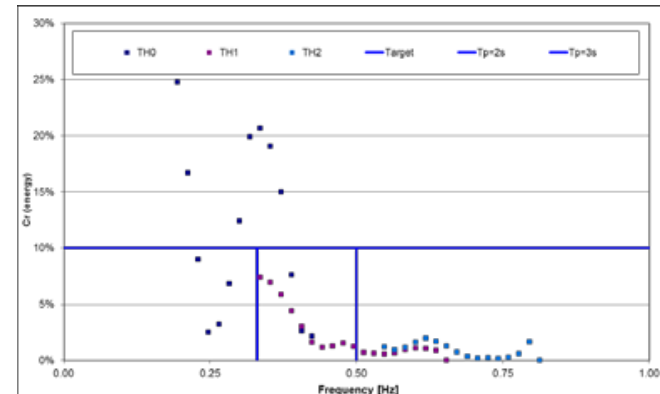

Figure 14.7

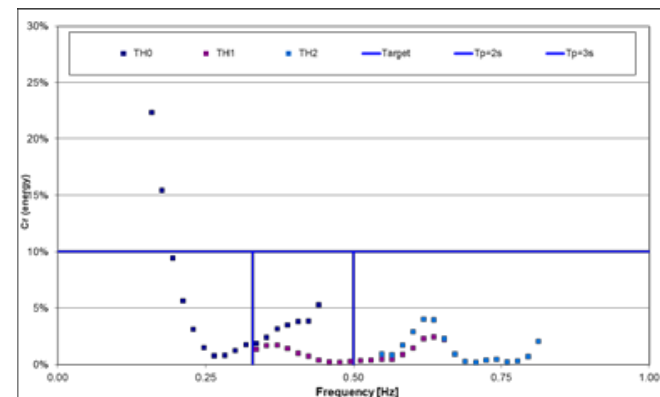

Figure 14.9

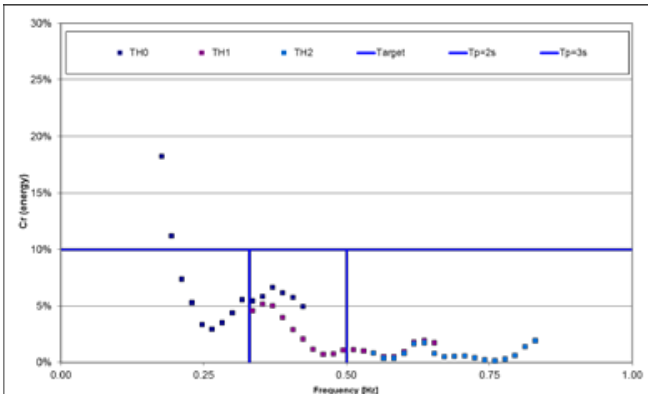

Figure 14.11

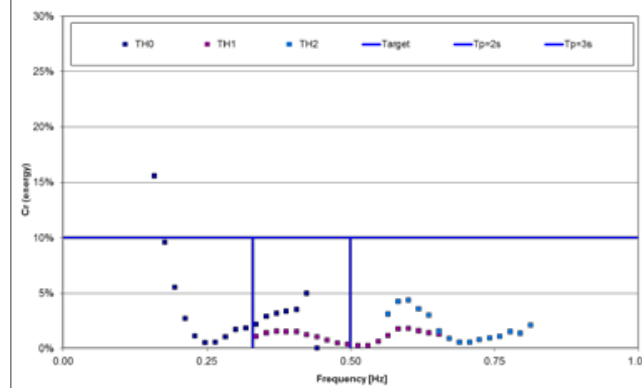

Figure 14.4

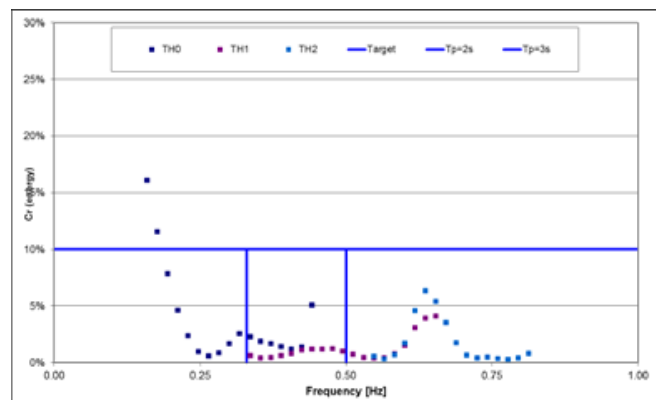

Figure 14.6

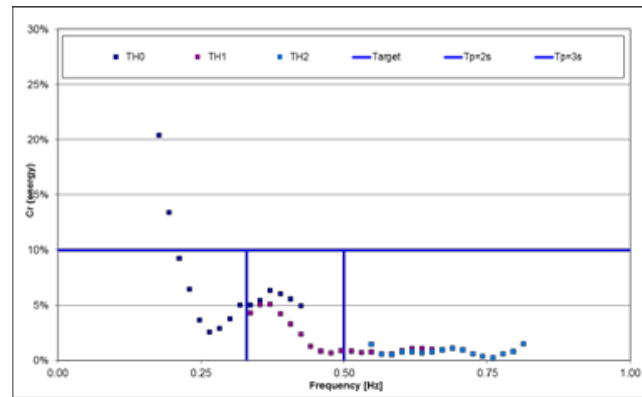

Figure 14.8

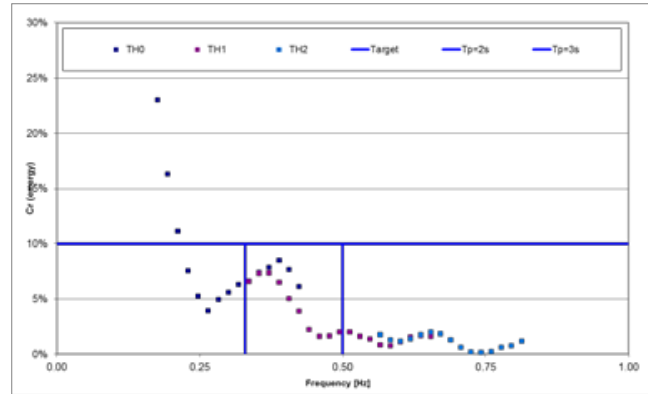

Figure 14.10

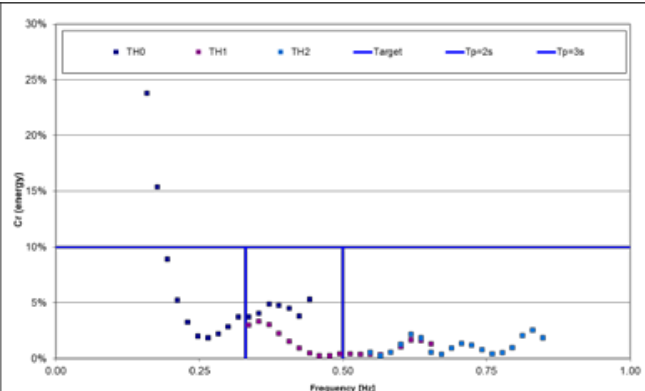

Figure 14.12 


\section{BIBLIOGRAPHY}

Allsop, N. W. H., 1995. "Vertical walls and breakwaters : optimisation to improve vessel safety and wave disturbance by reducing wave reflections”, Invited chapter in book, Wave Forces on Inclined and Vertical Structures - Editor Z. Demirbilek, ASCE, NEW YORK, 1995.

Allsop, N. W. H. \& McBride, M. W., 1994. "Reflections from vertical walls : the potential for improvement in vessel safety and wave disturbance", Paper to the 2nd MCS Project Workshop, Madrid, October 1993 [and in Proceeding International Workshop on Wave Barriers in Deep Water, Port \& Harbour Research Institute, Yokosuka, Japan, p. 101-128].

Allsop, N. W. H., McBride, M. W., Colombo, D., 1994. "The reflection performance of vertical walls and 'low reflection' alternatives - results of random wave flume tests”, Paper to the 3rd MCS Project Workshop, Emmelord.

Bergmann, H., Oumeraci, H., 1999. “Hydraulic performance of perforated structures”, COPEDEC V, Cape Town, South Africa, p. 1340-1349.

Cho, I. H., Kim, M. H., 2008. "Development of wave absorbing system using an inclined porous plates”, IWWWFB23 (International Workshop on Water Waves and Floating Bodies), 13-16 April, Jeju, Korea.

Chwang, A. T. \& Dong, Z., 1984. "Wave trapping due to a porous plate”, Proc. 15th Symp. on Naval Hydrodynamics, p. 407-417.

Dhinakaran, G., Sundar, V., Sundaravadivelu, R., Graw, K. U., 2001. "Pressures on a seaside perforated semicircular breakwater", Int Conf. in Ocean Engineering, 11-14 December.

Fryer, D. K., Mitchell, J. E., 1991. “A wave absorber for ship tanks and seakeeping model test basins”, Int. Shipbuild, Progr., 38, no. 416 (1991), p. 393-410.

Galleno, M., O’Doherty, N., Simons, R. R., 2002. “Experimental and theoretical assessment of novel wave absorbers”, ICCE, p. 1353-1363.

Gardner J, Townend I.W. \& Fleming C.A. (1986) "Design of a Slotted Vertical Screen Breakwater” Chapter 138, Proceedings ICCE, p. 1881-1893, Publn. ASCE, New York

Gardener J.D. \& Townend I.H. (1988) "Slotted vertical screen breakwaters" Proc. ICE Conf. on Design of Breakwaters, pp 283 - 298, ISBN 07277 1351 5, publn Thomas Telford, London.

Goda, Y. \& Ippen, A. T., 1963. "Theoretical and experimental investigation of wave energy dissipators composed of wire mesh screens”, Hydrodynamics Laboratory Report No.60, Department of Civil Engineering, Massachusetts Institute of Technology, Cambridge, Massachusetts.

Goda, Y. (1974), "New wave pressure formulae for composite breakwater, Proc. of 14th Int. Conf. Coastal Eng., Copenhagen, Denmark, ASCE, New York (1974), pp. 1702-1720.

Goda, Y. \& Suzuki, Y., 1976. "Estimation of incident and reflected waves in random wave experiments," Proc. 15th Coastal Eng. Conf., 1, p. 828-845.

Goda, Y., 1985. "Random seas and design of maritime structures", Advanced Series on Ocean Engineering, Vol. 15, World Scientific.

Götschenberg, A. \& Scheffer, H.-J., 1984. "Three dimensional investigations on wave reflection including irregular waves”, Fourth Congress-Asian and Pacific Division International Association for Hydraulic Research Chiang Mai, 11-13 September, Thailand.

Hughes, S. A., 1993. "Physical models and laboratory techniques in coastal engineering”, Advanced Series on Ocean Engineering - Vol. 7, World Scientific.

Jamieson, W. W. \& Mansard, E. P. D., 1987. “An efficient upright wave absorber”, Proc. Coastal Hydrodynamics Conf. ASCE, Newark, DE, p. 124-139.

Jarlan, G. E., 1961. “A perforated vertical wall breakwater”, The Dock and Harbour Authority, Vol. XII, No. 486, April 1961.

Johnson, J. W., 1945. "Rectangular artificial roughness in open channels”, Trans. Amer. Geophys. Union, May 1945.

Kakuno, S., 1983. "Reflection and transmission of waves through vertical slit type structures”, Proc. Coastal Structures '83, ASCE, Arlington.

Keulegan, G. H., 1972. "Wave damping effects of fibrous screens”, Research Report H-72-2, US Army Engineer Waterways Experiment Station, Vicksburg, Mississippi.

Keulegan, G. H., 1973. "Reflection characteristics of screen wave absorbers”, Research Report H-73-3, US Army Engineer Waterways Experiment Station, Vicksburg, Mississippi.

Kondo, H., 1979. “Analysis of breakwaters having two porous walls”, Coastal Struct. '79, Vol.2.

Lean, G. H., 1967. “A simplified theory of permeable wave absorbers”, Journal of Hydraulic Research, Vol 5, No.1, p. 15-30. 
Lebey, M. \& Rivoalen, E., 2002. "Experimental study of the working. Principal and efficiency of a superposed inclined planes wave absorber”, Ocean Engineering, 29, p. 1427-1440.

Le Mehaute, B., 1972. "Progressive Wave Absorber”, Journal of Hydraulic Research, 10(2), p. 153189.

Losada, I. J., Losada, M. A., Baquerizo, A., 1993. “An analytical method to evaluate the efficiency of porous screens as wave dampers”, Applied Ocean Research 15 (1993), p. 207-215.

Nagai, S. \& Kakuno, S., 1976. "Slit type breakwater : Box type wave absorber”, ICCE, Vol. III.

Nejadkazem, O., Gharabaghi, A. R. M., 2008. “A survey of passive wave absorbers”, The 4th National Conference on Civil Engineering, May 2008, University of Tehran.

Noble, H. M., 1979. "Low wave reflection construction at San Francisco", Proc. Coastal Structures '79, ASCE, Arlington, p. 576-587.

Onishi, H. \& Nagai, S., 1979. "Breakwaters and sea-walls with a slitted box-type wave absorber", Coastal Struct. 1979, Vol. 2.

Ouellet, Y. \& Datta, I., 1986. “A survey of wave absorbers”, Journal of Hydraulic Research, Vol. 24, No. 4, p. 265-280.

Pearson, J., 2009. "Hydrodynamics and pollution dispersion by long-shore currents. DHI-2-Mixing in the nearshore”, EC contract no. 022441 (RII3), HydralabIII.

San, S., Donslund, B., Hansen, K., Mathisen, N., 1982. “Optimization of absorbers for DHI’s offshore basin by means of 3-gauge reflection procedure”, Internal Report, Danish Hydraulic Institute.

Straub, L. G., Bowers, C. E., Herbich, J. B., 1957. "Laboratory tests of permeable wave absorbers", Proceedings of the 6th Coastal Engineering Conference, Council on Wave Research, The Engineering Foundation, p. 729-742.

Takahashi S. Tanimoto K. \& Shimosako K. (1994) "Dynamic response and sliding of breakwater caissons against impulsive breaking wave forces" Proceedings of Workshop on Wave Barriers in Deep Waters, pp362-401, Port and Harbour Research Institute, Yokosuka, Japan.

Twu, S. \& Lin, D., 1991. “On a highly effective wave absorber”, Coastal Engineering (15), p. 389-405.

Twu, S. W. \& Wang, Y. T., 1994. “A computational model of the wave absorption by the multilayer porous media”, Coastal Engineering 24, p. 97-109.

Weckman, J., Bigham, G. N., Dixon, R. O., 1983. "Reflection characteristics of a wave-absorbing pier”, Proc. Coastal Structures '83, ASCE, Arlington, p. 953-960.

Yeh, H. \& Mok, K. M., 1990. “Experimental Facility for Progressive Edge Waves”, Water Wave Kinematics, Ed. by Tørum, A. \& Gudmestad, O.T., Kluwer Academic Publisher, Dordrecht, 645648. 